\title{
RETROSPECTIVE EVALUATION OF CAUSES AND SOCIAL CORRELATES OF MATERNAL DEATHS AT ASSAM MEDICAL COLLEGE AND HOSPITAL, DIBRUGARH, ASSAM, INDIA
}

\author{
Milan Kumar Taye1, Anjuman Alam², Rakshita ${ }^{3}$ \\ ${ }^{1}$ Assistant Professor, Department of Obstetrics \& Gynaecology, Assam Medical College \& Hospital, Dibrugarh. \\ 2 Assistant Professor, Department of Obstetrics \& Gynaecology, Assam Medical College \& Hospital, Dibrugarh. \\ ${ }^{3}$ Post Graduate Trainee, Department of Obstetrics \& Gynaecology, Assam Medical College \& Hospital, Dibrugarh.
}

\section{ABSTRACT}

Reduction of maternal death to achieve MDG - 5 Target - 6 is a challenge for most of the developing countries of the world in spite of steady decline in maternal death. There is a great difference in MMR of developing and developed countries as well as within the countries, states, districts depending upon the socioeconomic and educational status. This study was conducted to estimate the MMR, evaluate the causes of maternal death and to formulate strategies for reduction of maternal death at Assam Medical College and Hospital, Dibrugarh, Assam.

\section{MATERIAL AND METHODS}

A retrospective study of causes of maternal deaths from 1st January 2012 to 31st August 2015 at Obstetrics and Gynaecology Department of Assam Medical College and Hospital, Dibrugarh, Assam, India. The records were collected from Maternal Death Register and analysis were made to find out the MMR, causes of maternal deaths and its contributing factors.

\section{OBSERVATIONS}

There were 279 maternal deaths out of 33833 live births giving MMR of 824.64. Hypertensive disorder of pregnancy (37.63\%) was the leading direct cause followed by infections (14.69\%) and hemorrhage (12.90\%) and the anaemia $(24.73 \%)$ was the commonest indirect cause of maternal death. Contributory factors like age, locality, booking visit play a major rule in mater nal death in our study.

\section{KEYWORDS}

Maternal Mortality Ratio, Infection, Hypertensive Disorder of Pregnancy, Direct and Indirect Causes, Anaemia.

HOW TO CITE THIS ARTICLE: Taye MK, Alam A, Rakshita. Retrospective evaluation of causes and social correlates of maternal deaths at Assam Medical College and hospital, Dibrugarh, Assam, India. J Evolution Med Dent Sci 2016;5(5):275-279,

DOI: $10.14260 /$ jemds/2016/59

\section{INTRODUCTION}

Maternal death $\mathrm{s}$ is defined as "The death of a woman while pregnant or within 42 days of termination of pregnancy irrespective of the duration and site of pregnancy, from any cause related or aggravated by the pregnancy or its management but not from accidental or incidental causes." $[1]$ Maternal Mortality Ratio (MMR) is the number of maternal deaths per 100000 live births. MMR ranges from 760 per 100000 live births in African countries to 8 per 100000 live births in industrialized countries.[2] Everyday in 2015, about 830 women died due to complications of pregnancy and child birth. Of the 830 daily maternal deaths 550 occurred in SubSaharan Africa and 180 in Southern Asia, compared to 5 in developed countries.

There has been $43 \%$ decline in maternal death worldwide from 1990 to 2015 which translates into an average annual decline of just $2.3 \%$ but to achieve the Millennium Development Goal (MDG) 5: Target 6 (75\% decline in MMR), the decline rate should have been 5.5\%.[3] The MMR in India is decreasing steadily. It was 212 (2007-2009), 178 (2010-2012) and 167 (2011-2013). The MMR of India was 420 in 1990 and MMR for MDG in 2015 is 109.

Financial or Other, Competing Interest: None.

Submission 05-01-2016, Peer Review 06-01-2016,

Acceptance 12-01-2016, Published 16-01-2016.

Corresponding Author:

Dr. Milan Kumar Taye,

DQ-25, E-Lane,

AMC Campus,

Dibrugarh-786002.

E-mail: taye.milon.dr@gmail.com

DOI:10.14260/jemds/2016/59
It is encouraging that a few states of India like Kerala (61), Maharashtra (68), Tamil Nadu (79), Andhra Pradesh (92) and Telangana (92) have achieved MMR below MDG Goal.[4] The MMR in Assam was 480 (2004-2006), 390 (2007-2009), 328 (2010-2012) and 300 (2011-2013).[4] For last few years Assam top the list of maternal deaths in India. The life time risk of maternal deaths in the age group 15-49 is $1.6 \%$ in Assam compared to $0.2 \%$ in Kerala during 2001-2003. As most of the deaths in Dibrugarh district and nearby districts occur at Assam Medical College and Hospital, it is very important to do a critical analysis of the causes and social correlates of maternal deaths in this institution.

\section{MATERIALS AND METHODS}

This is a retrospective analysis of causes and social correlates of 279 maternal deaths from January 2012 to August 2015 at Assam Medical College and Hospital, Dibrugarh, Assam. During this period, there were 33833 live births resulting in MMR of 824.64. The data was collected for publication from Maternal Death Register after taking permission from the Head of the department and the Superintendent of the institution.

\section{RESULTS AND OBSERVATIONS}

There were 279 maternal deaths during this period. Analysis of causes showed that $105(37.63 \%)$ maternal deaths occurred due to hypertensive disorder of pregnancy, 41 (14.70\%) due to infections (Septic abortion $12+$ puerperal sepsis 29), 36 $(12.90 \%)$ due to hemorrhage (APH-13, PPH-15, Ectopic- 5 , Abortion-3) in pregnancy. Severe anaemia was directly responsible for $69(24.73 \%)$ maternal deaths of which 2 cases were associated with Bronchial Asthma, one with cardiomyopathy and one with intestinal obstruction. 
It was also observed that severe anaemia contributed in $34(12.19 \%)$ out of 105 maternal deaths due to hypertensive disorder of pregnancy and $23(8.24 \%)$ out of 41 maternal deaths due to septicemia. There were $10(2.55 \%)$ maternal deaths due to obstructed labour, out which 6 had ruptured uterus. There were four $(1.43 \%)$ maternal deaths due to pulmonary embolism, four $(1.43 \%)$ due to jaundice, five $(1.792 \%)$ due to CNS causes (One due to GBS, one due to Myasthenia Graves, one due to meningitis, one due to quadriplegia with electrolyte imbalance and one due to epilepsy), one due to anaphylaxis following blood transfusion, one due to heart disease, two due to Adult Respiratory Distress Syndome (ARDS) and one due to anesthetic mishap. Direct causes were responsible for $68.82 \%$ (192) of maternal deaths and indirect causes were responsible for $31.18 \%$ (87) of maternal deaths in our institution.

Out of the 279 maternal deaths 231 (82.80\%) were unbooked and only $48(17.20 \%)$ were booked cases; 179 $(64.16 \%)$ were referred from different level of health care facilities and $100(35.84 \%)$ came directly from home. Out of 224 (80.29\%) maternal deaths were between age group of 20 30 yrs.; 29 (10.40\%) were less or equal to 19 yrs. and 26 (9.32\%) were age group of more than 30 yrs.; 146 (52.33\%) maternal deaths were primigravida, $65(23.29 \%)$ were second gravida, 40 (14.333\%) were third gravida and $28(10.03 \%)$ were fourth gravida and above.
Out of 279 maternal deaths $46(16.49 \%)$ maternal deaths were less than 30 kilometers, 96 (34.40\%) were $30-60 \mathrm{~km}, 108$ $(37.38 \%)$ were $60-100 \mathrm{~km}$ and $29(10.40 \%)$ were more than $100 \mathrm{~km}$ away from our institution. Maternal deaths in relation time of admission to death: Out of 279 deaths 40 (14.34\%) died within two hours of admission, 20 (7.17\%) died between two to four hours, 33 (11.83\%) died between four to 10 hours and $186(66.67 \%)$ died after 10 hours.

\section{Maternal Death in Relation to Gestational Age and Delivery}

Out of 279 maternal deaths $20(7.17 \%)$ patient died in early pregnancy, out of which 12 were septic abortion, 3 were incomplete abortion with hemorrhage and 5 were ectopic pregnancy. In late pregnancy 259 maternal deaths occurred, out of which $89(31.90 \%)$ died before delivery and 170 $(60.93 \%)$ died after delivery. Out of the 170 maternal deaths after delivery, 17 (6.09\%) delivery occurred at home and 14 (5.02\%) vaginal delivery and $07(2.51 \%)$ LSCS occurred at other institution \& 126 (45.16\%) were delivered at AMCH of which $73(26.16 \%)$ had vaginal delivery and $6(2.15 \%)$ had instrumental vaginal delivery (Forceps $6+$ craniotomy 2 ) and 47 (16.85\%) had emergency LSCS and 6 (2.15\%) had exploratory laparotomy.

\begin{tabular}{|c|c|}
\hline Direct Causes - 197 (70.61\%) & Indirect Causes - $82(29.39 \%)$ \\
\hline $\begin{array}{ll} & \text { Hypertension - } 105(37.63 \%) \\
\text { - } & \text { APE - } 53(18.99 \%) \\
\text { - } & \text { PPE - } 11(3.94 \%) \\
\text { - } & \text { HTN- } 41(14.70 \%)\end{array}$ & Severe anaemia - $69(24.73 \%)$ \\
\hline $\begin{array}{c}\text { Infection - } 41(14.70 \%) \\
\text { Septic abortion-12 (4.30\%) } \\
\text { Puerperal sepsis-29 (10.39) }\end{array}$ & Jaundice - $4(1.43 \%)$ \\
\hline $\begin{array}{l}\text { Hemorrhage }-36(12.90 \%) \\
\qquad \begin{array}{l}\text { APH }-13(4.66 \%) \\
\text { PPH }-15(5.38 \%) \\
\text { Ectopic-5 }(1.79 \%) \\
\text { Abortion } 3(1.08 \%)\end{array}\end{array}$ & $\begin{array}{l}\text { CNS disorder }-5(1.79 \%) \\
\text { Myasthenia graves }-01 \\
\text { Meningitis }-01 \\
\text { Epilepsy }-01 \\
\text { GBS }-01 \\
\text { Quadriplegia - } 01\end{array}$ \\
\hline Obstructed labor 10 (3.58\%) & Heart disease $-01(0.36 \%)$ \\
\hline Embolism 04(1.43\%) & Anaphylaxis due to blood transfusion - $01(0.36 \%)$ \\
\hline Anesthetic complication-01(0.36\%) & Acute respiratory distress syndrome - $02(0.72 \%)$ \\
\hline Table 1: Maternal & th in Relation to Causes \\
\hline
\end{tabular}

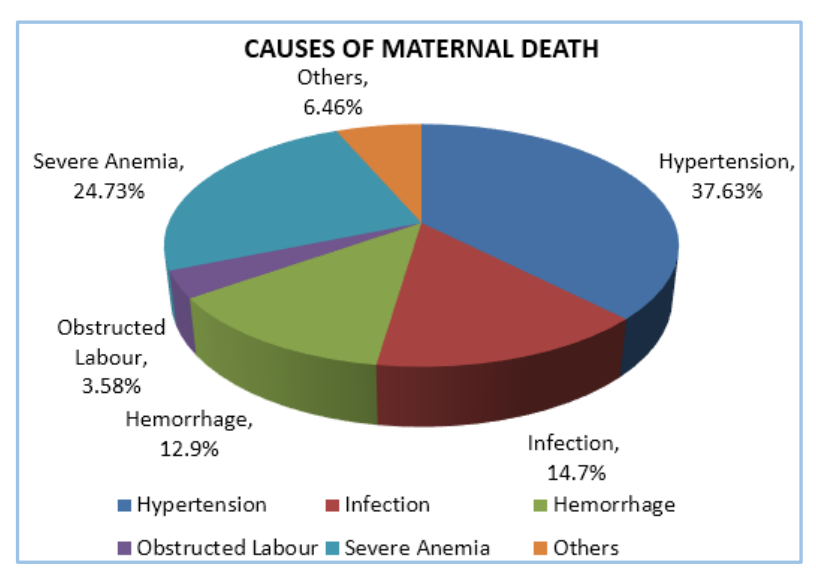

Severe anaemia contributed in 34 (12.19\%) out of 105 maternal deaths due to hypertensive disorders of pregnancy and in $23(8.24 \%)$ out of 41 maternal deaths due to septicemia.

So severe anaemia contributed in 57 (20.43\%) out of 279 maternal deaths.

\begin{tabular}{|c|c|c|}
\hline Unbooked & Booked & Total \\
\hline $\begin{array}{c}231 \\
(82.80 \%)\end{array}$ & $48(17.20 \%)$ & 279 \\
\hline \multicolumn{3}{|c|}{ Table 2: No. of maternal deaths in } \\
relation to booked/unbooked \\
\hline
\end{tabular}




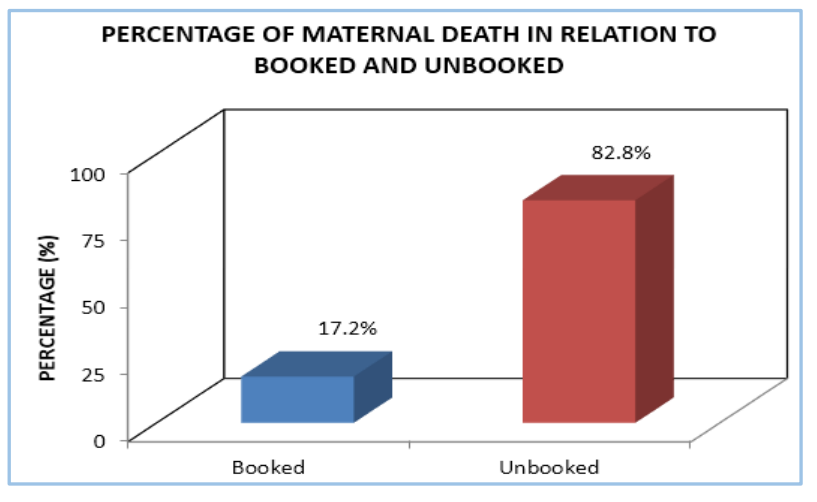

\begin{tabular}{|c|c|c|}
\hline Referred & Direct Admission & Total \\
\hline $179(64.16 \%)$ & $100(35.84 \%)$ & 279 \\
\hline \multicolumn{2}{|c|}{ Table 3: No. of maternal deaths in } \\
relation to status of referral \\
\hline
\end{tabular}

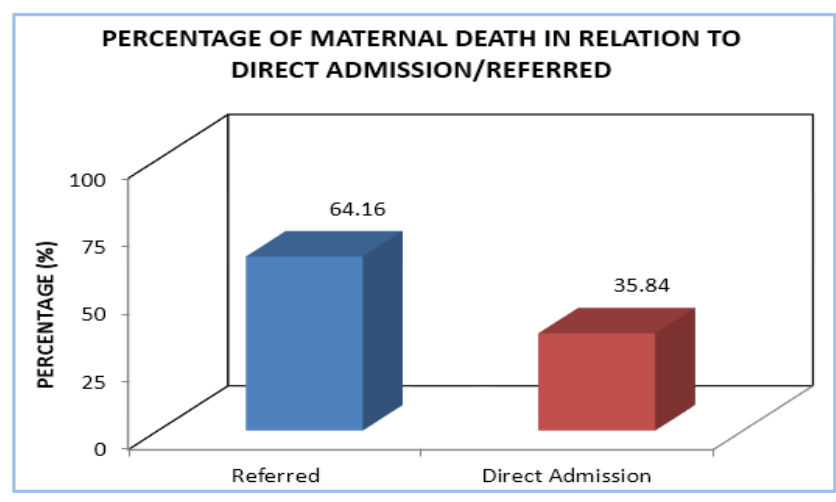

\begin{tabular}{|c|c|c|c|}
\hline <19yrs & 20 to 30yrs & >30yrs & Total \\
\hline $29(10.39 \%)$ & $\begin{array}{c}224 \\
(80.29 \%)\end{array}$ & $26(9.31 \%)$ & 279 \\
\hline \multicolumn{4}{|c|}{ Table 4: Number of maternal death } \\
in relation to age groups \\
\hline
\end{tabular}

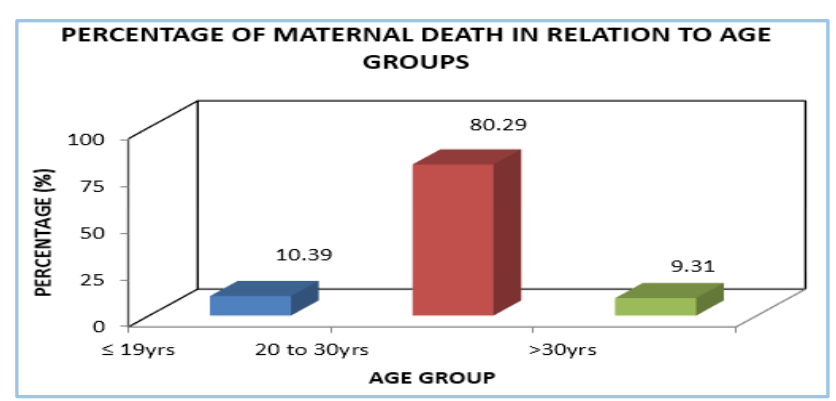

\begin{tabular}{|c|c|c|c|}
\hline Primigravida & $\begin{array}{c}\text { Second } \\
\text { Gravida }\end{array}$ & $\begin{array}{c}\text { Third } \\
\text { Gravida }\end{array}$ & $\begin{array}{c}\text { Fourth } \\
\text { Gravid } \\
\text { and above }\end{array}$ \\
\hline $146(52.32 \%)$ & $\begin{array}{c}65 \\
(23.30)\end{array}$ & $\begin{array}{c}40 \\
(14.34 \%)\end{array}$ & $28(10.04 \%)$ \\
\hline \multicolumn{3}{|c|}{ Table 5: Number of maternal } \\
death in relation to Gravida
\end{tabular}

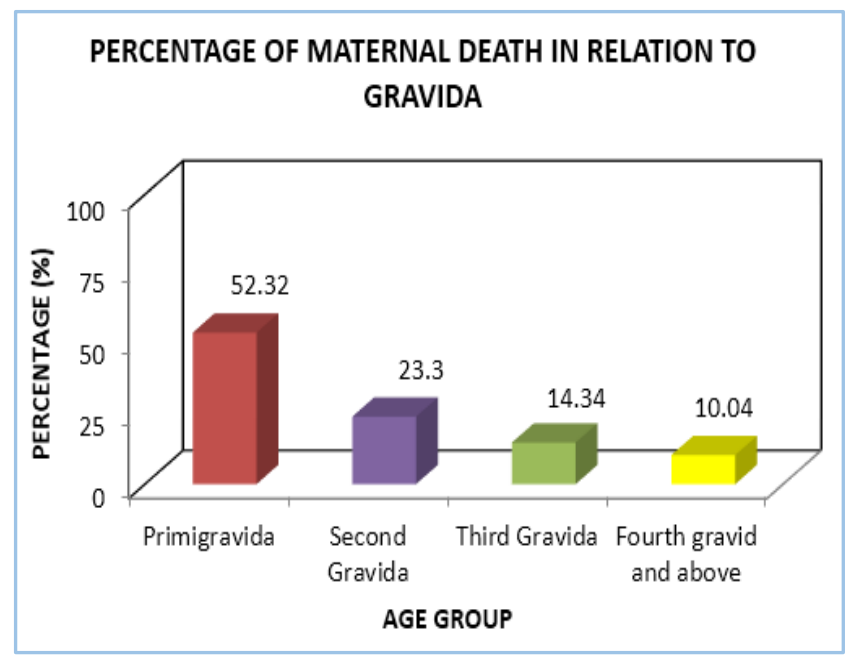

\begin{tabular}{|c|c|c|c|}
\hline ×30 KM & $\begin{array}{c}\mathbf{3 0} \text { to } \mathbf{6 0} \\
\text { KM }\end{array}$ & $\begin{array}{c}\text { >60KM to } \\
\text { 10oKM }\end{array}$ & $>$ 100KM \\
\hline $\begin{array}{c}46 \\
(16.49 \%)\end{array}$ & $\begin{array}{c}96 \\
(34.41 \%)\end{array}$ & $108(38.71 \%)$ & $\begin{array}{c}29 \\
(10.39 \%)\end{array}$ \\
\hline \multicolumn{3}{|c|}{ Table 6: Number of maternal death in } \\
relation to distance from our institution \\
\hline
\end{tabular}

\begin{tabular}{|c|c|c|c|}
\hline $\begin{array}{c}\text { < Two } \\
\text { hours }\end{array}$ & $\begin{array}{c}\text { Two to four } \\
\text { hours }\end{array}$ & $\begin{array}{c}\text { Four to 10 } \\
\text { hours }\end{array}$ & $\begin{array}{c}>10 \\
\text { hours }\end{array}$ \\
\hline $\begin{array}{c}40 \\
(14.34 \%)\end{array}$ & $20(7.17 \%)$ & $33(11.83 \%)$ & $\begin{array}{c}186 \\
(66.67 \%)\end{array}$ \\
\hline \multicolumn{3}{|c|}{ Table 7: Number of maternal deaths in relation } \\
to time interval between admission and death \\
\hline
\end{tabular}

Pregnancy Beyond 20 weeks

Undelivered - 89 (31.90\%)

- $\quad$ Home delivery- 17 (6.09\%)

- Vaginal delivery in other institution-14(5.02\%)

Ectopic - 5 (1.79\%)

- Laparotomy -2

- Vaginal delivery in our institution- 79 (28.31\%) [Forceps-

04; craniotomy-02]

- $\quad$ LSCS in other institution- $07(2.51 \%)$

- $\quad$ LSCS in our institution- $47(16.85 \%)$

- Exploratory laparotomy- 06 (2.15\%) [Rupture uterus - 06]

Table 8: Number of maternal deaths in relation to

gestational age and status of delivery \& intervention 


\begin{tabular}{|c|c|c|c|c|c|c|c|c|c|c|}
\hline & Chakr & orty & $\begin{array}{c}\text { Pal } \\
\text { Amitava }\end{array}$ & $\begin{array}{l}\text { Vidyadhar } \\
\text { B. Bangal }\end{array}$ & $\begin{array}{c}\text { Jadhav } \\
\text { C. A }\end{array}$ & $\begin{array}{c}\text { Varsha N. } \\
\text { Patil }\end{array}$ & $\begin{array}{c}\text { Surat } \\
\text { Zaman }\end{array}$ & $\begin{array}{c}\text { Sasikala } \\
\text { Mootha }\end{array}$ & $\begin{array}{c}\text { Nidhi } \\
\text { Gupta in } \\
\text { phase II }\end{array}$ & $\begin{array}{l}\text { Milan Taye } \\
\text { (Our Study) }\end{array}$ \\
\hline $\begin{array}{l}\text { Years of } \\
\text { study }\end{array}$ & $\begin{array}{l}1989- \\
1991\end{array}$ & $\begin{array}{c}200 \\
6- \\
200 \\
8\end{array}$ & $\begin{array}{l}1999- \\
2004\end{array}$ & $2006-2010$ & $\begin{array}{l}2007- \\
2012\end{array}$ & $2009-2011$ & $\begin{array}{l}2012- \\
2013\end{array}$ & $\begin{array}{l}2006- \\
2014\end{array}$ & $2012-2015$ & $1996-2005$ \\
\hline $\begin{array}{c}\text { Total live } \\
\text { births }\end{array}$ & 22748 & $\begin{array}{c}343 \\
18 \\
\end{array}$ & 83244 & 12544 & 39905 & 13188 & 10291 & 85404 & 33833 & 11878 \\
\hline $\begin{array}{l}\text { Maternal } \\
\text { Deaths }\end{array}$ & 254 & 166 & 519 & 38 & 158 & 63 & 73 & 183 & 279 & 282 \\
\hline MMR & 1051 & $\begin{array}{c}494 . \\
33\end{array}$ & 623.46 & 302.9 & 395 & 477 & 709.35 & 341.90 & 825 & 2374 \\
\hline $\begin{array}{c}\text { Age } \\
\text { Groups }\end{array}$ & & & & $\begin{array}{c}19-29 \text { yrs. } \\
68.42 \\
\end{array}$ & $\begin{array}{c}20-29 y r s \\
74.67 \% \\
\end{array}$ & $\begin{array}{c}20-29 y r s \\
74.60 \% \\
\end{array}$ & $\begin{array}{c}18-29 y r s \\
75.32 \% \\
\end{array}$ & $\begin{array}{c}20-29 \mathrm{yrs} \\
80.7 \% \\
\end{array}$ & $\begin{array}{c}20-30 y r s \\
80.29 \%\end{array}$ & $\begin{array}{c}\text { Mean age } \\
25.68 \\
\end{array}$ \\
\hline $\begin{array}{c}\text { Gravida- } \\
\text { primi }\end{array}$ & & & & $42.10 \%$ & $49.36 \%$ & $46.03 \%$ & $43.835 \%$ & $45.2 \%$ & $52.32 \%$ & \\
\hline $\begin{array}{l}\text { Booked/ } \\
\text { Unbooked }\end{array}$ & & & $\begin{array}{c}8.28 \% / 9 \\
1.72 \%\end{array}$ & $\begin{array}{c}28.94 \% / 7 \\
1.06 \%\end{array}$ & $\begin{array}{c}78.48 \% / \\
21.51 \%\end{array}$ & $\begin{array}{c}74.60 \% / 25.4 \\
\%\end{array}$ & $\begin{array}{c}\geq 4 \text { ANC } \\
8.62 \%\end{array}$ & $\begin{array}{c}66.8 \% / 3 \\
3.2 \%\end{array}$ & $\begin{array}{c}17.20 \% / 8 \\
2.80 \%\end{array}$ & $7.4 \% / 92.6 \%$ \\
\hline $\begin{array}{l}\text { Time of } \\
\text { admission } \\
\text { to death } \\
\text { in hrs. }\end{array}$ & & & & & & & & & $\begin{array}{c}21.52 \% \\
\text { died } \leq 4 \mathrm{hrs}\end{array}$ & $\begin{array}{c}33 \% \text { died } \leq \\
10 \mathrm{hrs}\end{array}$ \\
\hline $\begin{array}{l}\text { Direct } \\
\text { causes }\end{array}$ & $\begin{array}{l}60 \text { to } \\
71 \%\end{array}$ & $\begin{array}{c}66 \\
\text { to } \\
69 \% \\
\end{array}$ & $\begin{array}{l}>3 / 4^{\text {th }} \text { of } \\
\text { the total } \\
\text { deaths }\end{array}$ & $50 \%$ & $73.2 \%$ & $52.35 \%$ & $69.84 \%$ & $62.7 \%$ & $68.82 \%$ & $63.3 \%$ \\
\hline $\begin{array}{c}\text { Indirect } \\
\text { causes }\end{array}$ & $\begin{array}{c}28 \text { to } \\
39.5 \%\end{array}$ & $\begin{array}{c}30 \\
\text { to } \\
33 \%\end{array}$ & $\begin{array}{l}<1 / 4^{\text {th }} \text { of } \\
\text { the total } \\
\text { death } \mathrm{s}\end{array}$ & $50 \%$ & $26.8 \%$ & & $30.16 \%$ & $37.3 \%$ & $31.18 \%$ & $34.2 \%$ \\
\hline
\end{tabular}

Table 9: Comparison of our study with other studies

\section{DISCUSSION}

In our study direct causes were responsible for $70.16 \%$ and indirect causes were responsible for $29.39 \%$ of the total 279 maternal deaths out of 33833 live births (MMR-824.64). Hypertensive disorder of pregnancy $37.63 \%$, infection $14.69 \%$ (Septic abortion $4.30 \%$ ), hemorrhage $12.90 \%$ and obstructed labour $3.58 \%$ were the major direct causes of maternal death and severe anaemia was the commonest indirect cause solely responsible for $24.73 \%$ of maternal deaths in our study. Other indirect causes of maternal death in our study were CNS abnormality $1.79 \%$, jaundice $1.43 \%$, ARDS $0.72 \%$. Chakraborty S. et al. reported preeclampsia and eclampsia in $27.63 \%$, hemorrhage $26.60 \%$, unsafe abortion $6.49 \%$, anaemia $6.46 \%$ and pulmonary embolism $2.72 \%$.[5] Jadhav CA et al. reported reported hemorrhage $27.84 \%$, hypertensive disorder of pregnancy $10.75 \%$, sepsis $3.16 \%$, anaemia $33.33 \%$ and CNS disease $1.26 \%$ as causes of maternal death.[6]

Vidhyadhar B. Bangal et al. in their study reported eclampsia as the cause of death in $10.5 \%$, sepsis in $7.89 \%$, hepatitis in $21.05 \%$ and heart disease in $13.15 \% .{ }^{[7]} \mathrm{Pal}$ Amitava et al. in their study reported that major obstetrics complications accounted for three fourth of the maternal deaths including toxemia $50.56 \%$, sepsis $18.17 \%$ and hemorrhage $9.72 \%$. The major indirect causes for maternal deaths in their study were anaemia $4.18 \%$ and jaundice in $1.84 \%{ }^{[8]}$ Surat Zaman et al. in their study stated that eclampsia was the cause of death in $28.76 \%$, anaemia in $23.24 \%$, septicemia in $9.58 \%$ and septic abortion in $5.48 \% .{ }^{[9]}$ In Sasikala Mootha et al. study direct causes accounted for $62.7 \%$ of maternal deaths with eclampsia in $47.5 \%$, hemorrhage in $28.9 \%$ and sepsis in $23.4 \%$.
The indirect causes lead to $37.3 \%$ of maternal deaths with anaemia responsible for $15.5 \%$, jaundice $22.9 \%$, heart disease $21.1 \%$ and malaria for $7.3 \%$.[10]

Varsha N. Patil et al. reported hemorrhage in $28.57 \%$, hypertensive disorder of pregnancy $12.69 \%$, sepsis $6.34 \%$, uterine inversion $1.58 \%$ and obstructed labour in $3.17 \%$. Indirect causes included severe anaemia in $33.33 \%$, heart disease $17.46 \%$, liver disease $9.52 \%$, pulmonary disease $9.52 \%$, CNS disease $4.76 \%$ and acute renal failure, diabetes, malaria, laryngospasm each in $1.58 \% .{ }^{[11]}$ Nidhi Gupta et al. reported direct causes including hemorrhage in $26.6 \%$ (APH$6.2 \%$ and PPH- 20.4\%), toxemia $20.0 \%$, septicemia $12.6 \%$, rupture uterus $2.9 \%$ and ectopic pregnancy in $1.2 \%$ in Phase II. Indirect causes included anaemia in $22.9 \%$, ARF in $0.50 \%$, jaundice $7.2 \%$, heart disease in $1.7 \%$ and DIC in $1.9 \%$. Other causes reported were malaria in $1.2 \%$, blood transfusion in $0.5 \%$, meningitis or encephalitis in $0.4 \%$ and AIDS in $0.2 \%$. [12]

In comparison to other studies, except Surat Zaman et al. and Nidhi Gupta, our MMR was higher. This was because of high percentage of unbooked cases and referral cases from different districts, medical colleges and bordering states like Arunachal Pradesh and Nagaland. The percentage of maternal death due to severe anaemia was also very high in our study.

\section{CONCLUSIONS}

Complications of pregnancy and child birth is a major threat to the life of a woman in developing countries. Most of the causes of maternal deaths are multi factorial and preventable. A wellorganized multi-disciplinary approach including education, transportation, communication, poverty eradication and well equipped hospitals are required to reduce maternal death in the community in long run. 
Attitude to women needs to be changed in the society. Every pregnancy needs to be planned with judicial use of contraceptives.

Every healthy Indian needs to donate one unit of blood religiously at least every six months to prevent maternal death. Prevention of anaemia, hypertension, sepsis and well trained dedicated and challenging health staff are required to prevent maternal death at the earliest. The maternal deaths occurring at tertiary centre do not reflect the MMR of the community but it helps in evaluation of causes, strategy and planning to reduce maternal mortality.

\section{REFERENCES}

1. WHO (2005). Regional Health Forum, Vol. 9, No. 1, 2005.

2. UNICEF (2009). State of World's Children 2009.

3. WHO, UNICEF, UNFPA, the World Bank and the United Nations Population Division. Trends in Maternal Mortality: 1990 to 2015. World Health Organization, Geneva; 2015.

4. Sample registration system (SRS). Maternal \& child mortality and total fertility rates. Office of Registrar General, India 2013.

5. Chakraborty S, Sebanti G. Maternal mortality rate and its causes - changing trends in Kolkata, India. IJRRMS. 2012;2(1):16-18.
6. Jadhav CA, Gavandi Prabhakar, Shinde MA, et al. Maternal mortality: Five year Experience in tertiary care centre. Indian Journal of Basic \& Applied Medical Research. 2013;7(2):702-709.

7. Vidhyadhar B, Purushottam A, Giri B, et al. Maternal mortality at a tertiary care teaching hospital of rural India, a retrospective study. Int J Biol Med Res. 2011;2(4):1043-6.

8. Pal A, Ray P, Hazra S, et al. Review of changing trends in maternal mortality in a rural medical college in West Bengal, J Obstet Gynecol India. 2005;55(6):521-524.

9. Zaman S, Begum AA. Maternal mortality at a rural medical college of Assam: a retrospective study. J Obstet Gynaecol Barpeta. 2014;1(1):46-51.

10. Mootha S, Bathula U. Evaluation of maternal mortality rate (MMR) at a high volume tertiary referral centre: what are we missing? A study spanning 85,404 live births over 9 years. International Journal of Science and Research. 2013;4(1):302-304.

11. Patil VN, Shinde MA, Surve M, et al. Maternal mortality - a challenge? JKIMSU. 2013;2(1):58-61.

12. Gupta N. Changing trends in maternal mortalities rates - a retrospective study of 20 years at a tertiary teaching hospital of Uttar Pradesh. South Asian Federation of Obstetrics and Gynaecology. 2009;1(2):14. 